\title{
Discursive and Ethical Requirements of Court Trials ${ }^{1}$ \\ Wojciechowski B* \\ University of Lodz, Poland
}

\begin{abstract}
The results of the article will embrace: an innovative theoretical approach towards issue of democratic legitimation of the judicial rulings' influence on a system of law making, pioneering conceptualisation of judicial ethics based on the concept of communicative (discursive-democratic) competencies of judges, ground-breaking interpretation of judicial activism taken as a judicial participation in a system of institutional discourse of law making and finally the justification of critical assessment of Montesquieu's idea of the triple division of powers connected with an attempt to formulate an alternative. In this context biojurisprudence clarifies the issue linguistic and logical legalistic argumentations and interpretations of law, described in the trends of legal positivism, obscure more than elucidate that which they try to elucidate.
\end{abstract}

\section{Keywords: Court trials; Bioethics; Discourse}

\section{Introduction}

Communication in the form of discourse (justification or decision making) forces institutions to comply with certain normative requirements implied by the theory of the discourse. These requirements, nevertheless, are significantly modified by the subjective considerations of justice, and therefore, it becomes crucial to formulate the conditions of objective character. In the course of court trials, there take place confrontations between the assumptions and implications arising from the application of discourse theory to the democratic rule of law and the problem of the conditions of justice, particularly subjective ones, namely, burdens of judgment.

According to one of the research hypotheses, the concept of discourse as a reflective form of communicative action assumes the institutionalization of communication rules. It should be noted that, whereas the model of communicative action applies to the weak (i.e. non-institutionalized) public spheres, the discursive model applies to the strong, institutionalized spheres of public activity (it, therefore, is not only the legal discourse but also the political discourse, manifested in the parliament). This, in turn, raises the question of the extent of judiciary power as an expression of communicative power, legitimized by the latter. The starting point, therefore, is the thesis (which has, however, the nature of a research hypothesis) that discourse as a reflexive form of communication (undertaken for the purpose of justifying or making juristic and political decisions) forces institutions to comply with the specific normative requirements implied by the theory of the discourse.

It is traditionally pointed out that, in any argumentative (communicative) act, there are assumed a priori conditions of validity (of a normative character), which Jürgen Habermas refers to as claims to validity. ${ }^{2}$ The author of Theorie des Kommunikativen Handelns further believes that every participant in a speech act (speaker) speaks frankly and communicates true sentences in such a way that the listener finds the statement believable (correct) and that the participant's statement is right, namely, is accepted by the recipients in a given axiological

\footnotetext{
${ }_{1}$ The following text was prepared by as a part of a research grant financed by National Science Center (Poland), No. DEC-2013/11/B/HS5/04156.

$2 \mathrm{~J}$. Habermas, Vorstudien und Ergänzungen zur Theorie des kommunikativen Handelns, Frankfurt am Main 1984, p. 355. In colloquial communication claims to validity should constitute the assumption of rational communication. Claims to validity consist of understandability of speech (Verständlichkeit), truth (Wahrheit), reliability (Wahrhaftigkeit) and correctness (Richtigkeit) of the means of communication.
}

system. This practical discourse, within which the justification of normative statements takes place, as described, became the basis for the construction of the theory of legal discourse. The concept of legal discourse has been most widely discussed and developed by Robert Alexy, who treated it as a special case of a general and practical argumentation. ${ }^{3}$ It should be emphasized that the concept of legal discourse implies that it belongs to institutionalized discourses. In addition to appealing to the assumptions of the ideal speech situation, which is characteristic of a practical discourse, the legal discourse formulates pragmatic rules and forms of argumentation designed to serve rational and correct decision making.

Decisions made in this manner are rational and correct because they arise in the course of a free debate and ultimately reflect the beliefs of participants. The conditions assumed in the context of this procedure allow balancing specific reasons and ensure the right to compare one's own (judge's) claims to validity with those of others. The paradigm of applying law is the judicial application of law. In this framework, the legal discourse approaches the ideal speech situation because it takes place between unsubordinated participants in a dialogue in the context of an impartial and independent court which is not involved in the dispute. As well, claims to rationality and correctness constitute the basic features of the discourse. It can be stated that, in this sense, reality (here, the elements of a particular state of affairs and, specifically, of an individually adjudicated case) becomes the subject of negotiations during court trials because law is a form of social discourse, in which

${ }^{3}$ R. Alexy, Theorie der juristischen Argumentation, Frankfurt am Main 1978, p. $62 \mathrm{ff}$ The thesis that the legal discourse is a special case of a practical discourse is not universally accepted, but it has been subjected to extensive criticism. Critically, among others, U. Neumann, Juristische Argumentationslehre, Darmstadt 1986 p. 86; E. Hilgendorf, Argumentation in der Jurisprudenz, Zur Rezeption von analytischer Philosophie und kritischer Theorie in der Grundlagenforschung der Jurisprudenz, Berlin 1991, p. 109.

*Corresponding author: Wojciechowski B, University of Lodz, Poland, Tel: 0048426655992; E-mail: bartwoj@op.pl

Received January 30, 2016; Accepted March 15, 2016; Published March 17 2016

Citation: Wojciechowski B (2016) Discursive and Ethical Requirements of Court Trials'. J Clin Res Bioeth 7: 265. doi:10.4172/2155-9627.1000265

Copyright: @ 2016 Wojciechowski B. This is an open-access article distributed under the terms of the Creative Commons Attribution License, which permits unrestricted use, distribution, and reproduction in any medium, provided the original author and source are credited. 
all participants are equal and constrained only by rules of a procedural nature valid in a given case. ${ }^{4}$

It can be said that these highlighted features of the ideal judicial discursive situation create the discursive model of the judicial application of law, in which the settlement of disputes is carried out on the basis of dialogue and acceptance of an arbitrary judicial decision by the parties to legal disputes. A crucial element of the discursive model of the judicial application of law is the legal validity of the final decision because every modern continental legal system assumes that the closing argumentation is constructed in the form of the institution which decides the legal validity of the decision. Therefore, it is not required that the judicial decision in every case satisfy the condition of consensually complying with the universal claim of reason assumed in the theory of practical discourse. Compliance of the final decision with the text, values, and goals of the norms that belong to the existing legal order, though, is required. In other words, the rationality of the adjudicating body should be adequate according to current legislation and accepted legal culture and traditions, as well as to transcendentally understood rationality and the will of the legislator.

This assumption is also justified in the principle of the democratic rule of law, which stipulates that every decision should find its justification in applicable law. The theory of discourse involves binding the judge with the constitution and statutes and states that the mere normative text itself may not entirely determine an individual decision. To provide proper justification, it, therefore, becomes necessary to refer to the code of practical reason. This code not only limits the decision by the rules and principles resulting directly from the applicable laws but also lays out the complex of rules, which also includes the content of the law itself.

The principle of the democratic rule of law, with the attendant obligation to provide justification and the possibility to verify every decision based on relevant legal provisions, can be treated as a codified special case of a discourse of ethics. ${ }^{5}$ It follows that, in the theory of legal discourse which consolidates the positivist understanding of legal norms, the fact of being bound by law is also understood as being bound by the ensuing values and goals. The judge is not allowed to settle disputes contrary to the unequivocal wording and purpose of a particular norm. If allowed freedom in such an evaluation, particularly in balancing certain principles and objectives which influence the choice of a given legal consequence in an adjudicated case, the judge should follow, in addition to the statutory guidelines, a discursively realized claim to rationality and other rules of practical discourse. The process of applying the law and balancing the different forms and rules of arguments, rules of practical discourse, and principles of law should be based on the limits arising from the argumentation bound by the formal principle of the rule of law. Such decisions should always be as close as possible to the aims and values arising from the applicable legal text and from the valid legal order, which guarantees its greater importance in argumentation.

The subject matter of this article is also of utmost importance to

${ }^{4}$ A. Kozak, Granice prawniczej władzy dyskrecjonalnej [The Limits of Juridical Discretionary Power], Wrocław 2002, p. 31, 136ff; M. Zirk - Sadowski, Pozytywizm prawniczy a filozoficzna opozycja podmiotu i przedmiotu poznania [Legal Positivism and the Philosophical Opposition of the Subject and the Object of Cognition], [in:] Studia z filozofii prawa [Studies in the Philosophy of Law], ed. J. Stelmach, Kraków 2001, p. $83 \mathrm{ff}$.

${ }^{5}$ Cf. R. Christensen, Gesetzesbindung oder Bindung an das Gesetzbuch der praktischen Vernunft - Eine skeptische Widerrede zur Vorstellung des sprechenden Textes, [in:] Die Leistungsfähigkeit des Rechts, ed. R. Mellinhoff, H.-H. Trufe, Heidelberg 1988, p. 120 the ever increasing crisis of the judiciary, especially in legitimizing its law-making activity. It appears that the essence of the dispute between citizens and judges lies in differing understandings of professional ethics. In most discussions, this problem refers only to the ethics of judges, understood as the moral control of this profession by society. Meanwhile, recent years have revealed a problem in the broader role of ethics in the correct manner of carrying out this profession. For citizens, it is not only important how the judge behaves in public and whether he is an honest man. There is an increasing social demand for judges to take an active approach in the face of bad law; therefore, this problem can be referred to as a dispute about the role of the judge in culture.

Today, there can be distinguished two discussions about the ethics of the judge, which are parallel to each other and have a number of contact points. One discussion concerns judges' and lawyers' degree of moral accountability for the active improvement of law in the process of its application. The second discussion constitutes the traditional argument about the values that should be protected and complied with by the corporation of judges, namely, the question of the deontology of this profession. The first discussion is much more important from the perspectives of the considerations in this article.

In contemporary Polish jurisprudential literature, this topic is discussed in the context of the question not of whether the courts in our system of law have law-making powers but, rather, of whether such powers should be vested in them. ${ }^{6}$ Currently, the prevailing view is that it is possible in some cases to speak of the need for a law-making role for courts. This role prominently but not exclusively (as discussed later in this article) involves the stage of interpretation, which consists of the determination of the meanings of the phrases in the legal text and the mental activity leading to the conclusion of which norms of conduct are included in the legal text. I do not object to the view that there is a degree of freedom in judicial decisions connected, for example, with interpreting the semantic openness of legal concepts or, even under a positive law system, taking into account the decisions of other courts that have adjudicated similar cases (more specifically, the ratio decidendi of such decisions). It is also a common practice in the Polish legal system to refer to the merits of other rulings or the views expressed in the judgments of higher courts. Judges recognize such justification as fuller and more persuasive ${ }^{7}$ because it is based on the authority of a higher court (in Poland, this applies to the decisions of the Supreme Court and the Supreme Administrative Court). In this case, judicial discretion involves choosing the appropriate forms of arguments

${ }^{6} \mathrm{Cf}$., inter alia, A. Stelmachowski, Prawotwórcza rola sąów (w świetle orzecznictwa cywilnego) [Law-making Role of Courts (in the Light of Civil Judicature)], Państwo i Prawo 1967, no. 4 - 5; J. Wróblewski, Sądowe stosowanie prawa a prawotwórstwo [Judicial Application of Law and Law-Making], Państwo i Prawo 1967, no. 6; M. Zirk - Sadowski, Problem nowości normatywnej [The Problem of Normative Novelty], Studia Prawno - Ekonomiczne 1979, vol. XXII; M. Zirk - Sadowski, Tak zwana prawotwórcza decyzja sądowego stosowania prawa [So-Called LawMaking Decision of Judicial Application of Law], Studia Prawnicze 1980, vol. 1 - 2; Z. Ziembiński, Tworzenie a stanowienie $i$ stosowanie prawa [Creating and Making as well as Applying Law], Ruch Prawniczy, Ekonomiczny i Socjologiczny 1993, vol. 4; L. Morawski, Precedens a wykładnia [Precedence and Interpretation] Państwo i Prawo 1996, no. 10; P. Sut, Problem twórczej wykładni przepisów o ochronie dóbr osobistych [The Problem of Creative Interpretation of the Provisions of the Protection of Personal Interests], Państwo i Prawo 1997, no. 9; A. Orłowska, Stosowanie a tworzenie prawa w Polsce (uwagi o roli orzecznictwa sadowego w systemie źródeł prawa) [The Application and Law Making in Poland (Notes about the Role of Judicial Decisions in the System of Sources of Law)] Przeglad Sadowy 1999, no. 10; Z. Kmieciak, Prawotwórstwo sędziowskie w sferze jurysdykcji sądów administracyjnych [Judicial Law Making in the Sphere of Administrative Courts Jurisdiction], Państwo i Prawo 2006, no. 12.

${ }^{7}$ Cf. E. Łetowska, Pozaprocesowe znaczenie uzasadnienia sądowego [Extra-Trial Meaning of Judicial Merits of Decisions], Państwo i Prawo 1997, no. 5. 
and finding a balance between the applied interpretative rules and the principles of law when it is not possible to read the meaning of a specific legal provision literally (and it is almost never possible due to the ambiguity and vagueness of legal concepts). Thus, the problem of formalism means that the so-called hard cases, ${ }^{8}$ which require referring to a certain axiological background, are also treated by it as situations in which the final decision is determined utterly by the legal text. A legal text, though, often does not provide a clear answer, and the matter must be settled. In this context, John Gray aptly notes that "the application of law can be regarded as applying the theory of justice in individual cases and cases that are not so difficult that they could not be resolved."

Significantly, this discussion applies almost exclusively to the interpretative stage but also-to a very small extent-to the stage of determining facts, or to evidentiary proceedings. Yet it is in these proceedings that the court verifies parties' claims about certain facts relevant to the adjudication of the case (facts, therefore, are treated as an ontological category). Clearly, every interpretation relies on some sort of evidence, on a practice or entity, ${ }^{10}$ for otherwise, we are dealing only with academic considerations.

From the perspective of a particular adjudicated case, this stage of applying law is the most crucial because it allows presenting the facts relevant to a particular contentious issue. Public discourse most frequently analyses the adjudicated case through the prism of factual findings and conclusions drawn from them. Justice is seen only through the lens of the truth and the speed of resolving disputes, which are the qualities of a classic adjudicative model. ${ }^{11}$ Negative attitudes in Polish society toward the judiciary are caused, at least partly, by an improper practical implementation of the right to access courts. Justice makes sense only when parties do not wait for an excessively long period of time for a final decision and when the decision is naturally justifiable. I aim to take a closer look at this aspect in this paper.

Simply put, the issue of interest concerns the question of whether the court (the judge) should assist parties in investigating or proving the truth or whether the judge should maintain the attitude of a passive arbitrator who only cares about compliance with the rules of the game, not helping anyone in the process of argumentation. In other words, there arises an argumentative question of whether court trials ${ }^{12}$ should

${ }^{8}$ More broadly on this issue, see B. Wojciechowski, Rozstrzyganie tzw. trudnych przypadków poprzez odwołanie się do odpowiedzialności moralnej [Settling the so-called Hard Cases by Referring to Moral Responsibility], Studia Prawno Ekonomiczne 2004, No LXX, pp. 9-26.

9 J. Gray, Dwie twarze liberalizmu [Original title: The Two Faces of Liberalism] Warszawa 2001, pp. $33-34$.

${ }^{10}$ Similarly see: R. Dworkin, Law's Empire, Cambridge Mass. 1986, pp. 50 - 51.

${ }^{11}$ Traditionally there are distinguished four basic models (types) of resolving legal conflicts: consensual, based on mediation and conciliation, based on arbitration and adjudicative one. A feature of the latter is that the dispute is resolved by a formally appointed body (without the will of the parties), and the process of issuing the decision is carried out according to the procedures formally imposed on the parties. A paradigm of an adjudicative model of resolving conflicts is court trial.

${ }^{12}$ The transition to an adversarial model does not mean that judicial authorities are not obliged to strive for the detection of objective (material) truth. The principle of material truth consists in a directive, according to which the resolutions of the judicial authorities should be based on real facts consistent with reality. In case of adopting the principle of formal (judicial) truth, it is possible to be content with formal surrogates of truth or legal fiction, since the facts presented and demonstrated by the parties during the trial will be binding. The court has no obligation here to investigate the "truth," understood as the judgement consistent with the reality to which it refers. The findings of the court should be consistent only with the evidence collected in the case. Adversarial model is associated primarily with the common law tradition: "Closely connected with the common law tradition is the adversarial process by which two parties to a case present their evidence to the court, and the court decides the outcome. Two features of the adversarial process are particularly important: the passivity of the judge (and court) and the activity of the adversaries" be of an inquisitive or adversarial character and whether they should be governed by the principle of material truth, or, rather, formal truth.

In this sense, law is a field of activity in which Foucauldian parallels with war are easy to apply and justify. In the courtroom, as in war, the concepts of right and wrong, fairness and justice are formed by the winner. Naturally, the laws of war and the formal and material requirements of law are not completely dominated by the winners, who are themselves shaped by the law. To some extent, law is a linguistic game with very complex and unintelligible rules. The rules of the game are unclear (or even, due to open textuality of law, uncertain), so it is a contentious issue whether the parties to a given dispute can independently take care of their interests. This question raises several momentous issues crucial not only for lawyers but also for society, such as the actual implementation of the right to access courts, the elimination of excessively lengthy examinations of cases, the equality of all parties before the law, and the impartiality of courts. In the general discussion of justice, there arises the issue of competition between principles: objective truth and prompt proceedings, formal truth and impartial courts, or, finally, time-barred evidence and the right to a fair hearing. ${ }^{13}$

We sometimes have to ask whether we prefer a longer trial which may allow discovering the truth to a greater extent or whether we are rather extreme formalists in this regard and believe that such admission of evidence by the court of its own motion leads to violations of the constitutionally guaranteed impartiality of courts and equality of all parties before the law. The answer to this question is weightier because the strong position of the judiciary is an essential guarantee of the due implementation of the fundamental values of the democratic rule of law, including the constitutional rights and freedoms of the individual. The modern state is characterized by the provision of appropriate legal protection by sovereign, independent courts.

When revisiting the question of the classical understanding of judicial activism, Friderick Schauer accurately notes that an extremely formal approach to interpreting law has negative effects on the quality of public discourse about law as such. Hiding or avoiding axiological choices under the veil of the need for linguistic understanding of law prevents addressing questions about how this choice was made and whether it should be done otherwise. ${ }^{14}$ The judge should always keep in mind that he belongs to the so-called interpretive community, and as such, he implements Ronald Dworkin's institutional morality of the community of judges, or the common outlook of judges on the purposes of law and justice..$^{15}$ The judge, therefore, should refrain from imposing his own vision of the world or social or economic relations

(H. Jacob [in:] H. Jacob, E. Blankenburg, H. Kritzer, D. Provine, J. Sanders, Courts, Law and Politics in Comparative Perspective, New Haven-London 1996, p. 23). In other words, the parties will decide whether they present evidence or statements in order to justify their position or not. The court in principle should not have any probative initiative here.

${ }^{13}$ The introduction of the institution of time-barred evidence is associated with crucial rigors of the possibilities and the allowed time to present the parties statements, facts, and providing their justification based on the relevant evidence. Accordingly, if we do not comply with the relevant deadline set forth in law, we can no longer continue to defend our position and we lose our case, although in reality we should win it. For example, in commercial matters there applies time-barred evidence, according to which the claimant should submit all the evidence and facts already in the writ, and the defendant - in a response to the writ. If any party fails to comply with this duty, the court will not admit the evidence submitted at later time and will settle the case as if this evidence has not been submitted at all.

${ }^{14}$ F. Schauer, Formalism, "Yale Law Journal" 1988, no. 97, p. 514 ff.

${ }^{15}$ M. Smolak, Legalizm a polityczne problemy sądowej wykładni prawa [Legalism and Political Problems of Judicial Law Interpretation] [in:] Prawoznawstwo a praktyka stosowania prawa [Jurisprudence and the Practice of Law Application] eds. Z. Tobor, I. Bogucka, Katowice 2002, p. $171 \mathrm{ff}$. 
and should not take a particular philosophical standpoint. The judge, instead, should be guided by principles that are objectively legitimate from the perspective of political morality and that accord with the legal institutions resulting from the existing legal order. ${ }^{16}$

The tendency to harmonize judicial procedure, which is gaining in popularity, prompts considerations about a kind of universal art of judging. Due to the elimination of discrepancies, various national procedures have become clearer and more precise, which is especially important in the context of integration amid an era of continuous movement and cross-border legal relations. The need for a harmonized legal system results from the necessity to pursue the principle of justice, particularly procedural justice. Nowadays, one cannot ignore the claims which imply the existence of a certain common (similar) way to reach an outcome and discuss a ruling with the parties to a proceeding. It is difficult to the extent that we are dealing with worldwide pluralism and a growing diversity of normative and value systems. Consequently, it is necessary to carry out certain reforms of the administration of justice. However, this should entail not only making changes to functional or procedural terms but primarily reevaluating the philosophical and ideological attitudes of judges themselves.

The judge should realize that he has extensive power over the individual participants in social interactions taking place before him in the courtroom. He, therefore, must be a full-fledged participant in the process of argumentation, seeking to extract the natural law which, based on his own judgment, is ethically acceptable in a given community because there are valid and objectively good reasons favoring it. The judge ought never to be guided by opportunistic considerations. $\mathrm{He}$ should not be characterized by indolence at law and may not, under any circumstances, give up participating in the legal discourse. Thus, there appears the intriguing issue, especially in the context of European integration, of the participation of lawyers, particularly judges, in culture. The actual participation of judges in culture can provide public support for the decisions issued by them. ${ }^{17}$

In the decision-making process, the judge should be always guided by the rules and forms of arguments in the legal discourse. The importance of complying with these is inextricably linked to judges' reflexive realization of what an important role they play in society. In the course of a trial, the judge should strive, by behaving appropriately, to render a judgment that implements the rules governing the discourse understood as "the speech regulated by the moral requirements." ${ }^{18}$

The requirements of legal ethics often only detail the general requirements arising from the practical discourse. It is important, however, that fulfilment of these requirements enables knowledge (understanding) of the law as a specific cultural object. Such knowledge is made possible through the communication activities whose criteria of rationality include, as shown, ethical requirements.

Judicial activism is based on knowledge of the law as dependent on the ethical requirements posed by the legal discourse. It rejects the

${ }^{16} \mathrm{Cf}$. R. Dworkin, Biorąc prawa poważnie [original title: Taking Rights Seriously], Warszawa 1998, pp. $56-72,156-164$.

${ }^{17}$ Cf. E. Noelle - Neumann, Welche Rolle spielt die Öffentliche Meinung für die Entscheidung der Richter?, [in:] Staatsphilosophie und Rechtspolitik. Festschrift für Martin Kriele zum 65. Geburtstag, eds. B. Ziemske, T. Langheid, H. Wilms, G. Haverkate, München 1997, pp. 514 ff.

${ }^{18} \mathrm{Cf}$. M. Zirk - Sadowski, Dyskurs jako mowa regulowana wymogami moralnymi [The Discourse as Speech Regulated by Moral Requirements] [in:] Prawo w zmieniającym się społeczeństwie: księga jubileuszowa profesor Marii Boruckiej Arctowej [Law in a Changing Society: The Jubilee Book of Professor Maria Borucka - Arctowa] ed. G. Skapska, Kraków 1992, p. 189. concept of law as an object of cognition which is objective and purely external to the lawyer. It assumes that law has many sources, of which statutes are only one. The law is justified by the authority of the nation, and therefore, the will of the legislator may be only one benchmark for the judge. The legal text only clarifies the law, which does not end in the mere legal provision. The judge acts as the guarantor of such broadly defined law against the arbitrariness of the legislator. ${ }^{19}$ Support for this understanding of the application of law is most clearly seen in the jurisprudence of the Constitutional Court, Supreme Court, and Supreme Administrative Court. Here, the court is presented an instrument that protects the citizen against arbitrary action on the part of the legislator.

From the criticism of textualism has emerged a new concept of the role of the judge and the judging process. In positivist textualism, judging as an autonomous cultural activity is characterized by the independence of law from politics, the legitimization of state power through law, the control and limitation of compulsion, the acceptance of the pluralism of moralities as an axiological background, the test of the legality of acts of law making and law application, and the justification of legal decisions based on formal compliance with law. In positivism, the essence of judging is to create normative sense of the legal text. Initially, positivism did not seek the linguistic mediation of law, assuming that the content of law can be known only through the linguistic correctness of the text, which itself achieves readability in a manner consistent with the intent of the legislator. Eventually, though, classic legal positivism led to the instrumentalization of the judging process. Only rejecting positivist textualism and adopting judicial activism changes the cognitive situation of the judge and gives him the opportunity to bear ethical responsibility for the content of law. On the basis of anti-positivist activism, it is the task of judges and jurisprudence to seek the best possible understanding of law in the context of the norms and values of a given culture. ${ }^{20}$ In this way, the judiciary becomes a reality because through the judging process, and judges gain power over the integration of normative meanings into culture.

Due to the discursiveness of law, the rights of parties are indirectly contained in law, even in cases of ambiguous legal rules, through the normative context of social life. The judge does not build a normative sense by describing as law an object that exists objectively. Law is not waiting for him or finished when the lawmaker utters it. In activist theory, the judge formulates arguments in support of claims on the rights and obligations of the entities of law. In this spirit, Dworkin criticizes positivism, pointing to the need to take into account circumstances outside the legal system which could serve as a justification (and, in this sense, legitimization) of basic deontological legal claims. Doing so is precisely the function performed by the principles of law, which, in view of the above, are not directly associated with any sanctions (in other words, they do not assume the form of the rules of law). As entirely basic or fundamental normative formulations, they cannot be calculated with any collective aim. Consequently, though, they provide legal arguments to indicate which important norms (already in the sense of legal rules) apply to a particular case-to the actual situation examined in normative (legal) interpretation. At this point, it should be specified that "the arguments referring to principles are intended to establish the rights of the individual; the intention of political arguments

${ }^{19} \mathrm{Cf}$. H. Rabault, Granice wykładni sędziowskiej [Limits of Judicial Interpretation] Warszawa 1997, p. 10; also A. Kozak, Granice prawniczej..., op. cit., p. 122 ff.; J. Stelmach, Współczesna filozofia interpretacji prawniczej [Modern Philosophy of Legal Interpretation], Kraków 1995, chapter II; M. Zirk-Sadowski, Prawo a uczestniczenie w kulturze [Law and Participation in Culture], Łódź 1998, p. 57 ff. ${ }^{20}$ R. Dworkin, Law's Empire, London 1986, pp. 410-411. 
is to establish the collective aim. The principles are sentences describing rights; policies are sentences describing aims." ${ }^{21}$

Nevertheless, as Habermas notes, it must be made clear that, in Dworkin's theory, extra-legal arguments (moral arguments) justify the validity of the basic legal norms (principles) because the different languages of law and morality, or the different modes of the validity of moral and legal norms, mean that the overlap between these two types of norms overlap "does not stand for the immediate moralization of law." ${ }^{22}$ In other words, according to Habermas, Dworkin's theory reconciles the past with the present, history with the claim to justice. This reconciliation is the basis for referring to his concept as "the third way" in jurisprudence. Through such behavior, the judge is not only an arbiter adjudicating a case but also a reconciler and actual participant in the argumentation process.

\section{Conclusion}

The most current debates in the state of the art underlie two apparently contradictory problems, namely, (i) moral responsibility of a judge for improving law through the process of application of this

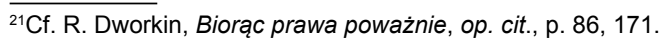

22J. Habermas, Faktyczność i obowiązywanie. Teoria dyskursu wobec zagadnień prawa i demokratycznego państwa prawnego [Factuality and Validity. The Theory of Discourse vis-à-vis the Issues of Law and Democratic State of Law], Warszawa 2005, p. $223 \mathrm{ff}$. law and (ii) judges' commitment to protect certain values, fundamental to a (certain) system of law. In our view, however, the two problems recall the third and much more basal as well as fundament issue of judicial communicative competencies. The concept of communicative competencies, in particular, discursive-democratic competencies refers to interpreting a certain legal text but also to understanding, interpreting and articulating moral norms and ethical or political values as well as potential conflicts between them which one may always find out behind the legal text and a certain branch. More important is even their relevance to, and condition for, the full participation in the discursive community of judges, the community that constructs 'a chain novel', that is the leading interpretative strategy of the judicature with regard to the most fundamental principles. Crucial, however, seem to be discursive-democratic competencies of judges, which in this case could be even called a most profound condition, for their possibility in partaking in a broader institutional setup design for law making activity. A great number of statutes and judicial decisions have dealt in recent years with problems of birth, life, and death. We must agree that one of the most important tasks of legal regulation is the prohibition of risky experiments that may bring about unforeseeable results in most cases; this will be linked with biology, medicine, and sometimes with psychiatry. In this context we should agree that biojurisprudence lies at the very core of "the paradigm of law" and, by its emergence as an independent discipline. It demonstrates the spiritual power of law as a culturally sensitive sphere. 